\title{
Lingkungan Belajar di Era New Normal di TK Matuari Werot
}

Ireyne Anggreini Atuy, Zefanya Junike Lolong, Yehezkiel Situmorang

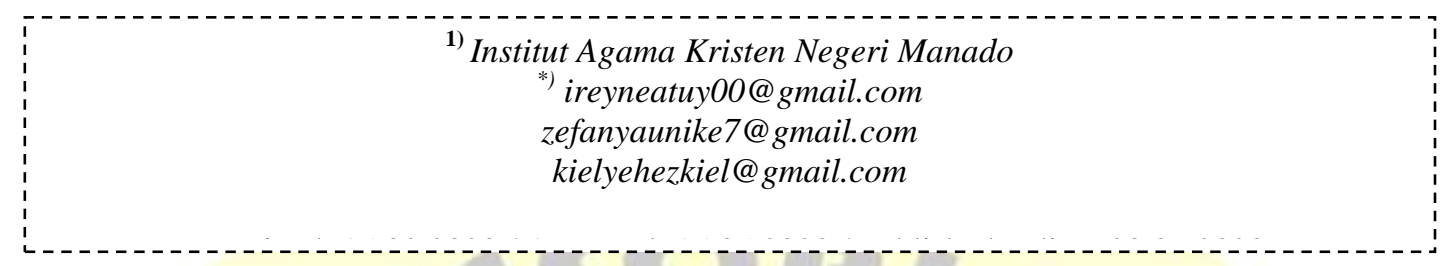

Abstrak

Dalam pembelajaran harus diperhatikan lingkungan belajar apalagi di era new normal ini pembelajaran sudah mulai dilakukan tatap muka meskipun masih menggunakan sesi, untuk itu guru harus kembali menyesuaikan lingkungan belajar setelah melewati pembelajaran daring. Guru dituntut agar mampu menata lingkungan dengan efektif. Perlu adanya penataan lingkungan belajar yang sesuai dengan era new normal agar dapat menghasilkan pembelajaran yang efektif, aman serta menyenangkan bagi anak. Tujuan penelitian adalah untuk mengetahui lingkungan belajar yang sesuai dengan era new normal. Adapun metode yang digunakan dalam penelitian ini yaitu metode kualitatif dengan teknik pengumpulan data yaitu wawancara dan observasi kepada guru yang menjadi penata atau pengatur lingkungan belajar di TK Matuari Werot. Hasil penelitian ini menunjukan bahwa lingkungan belajar di TK Matuari Werot sudah cukup efektif dan fasilitasnya sudah memenuhi kebutuhan sekolah tersebut, hanya saja penataan lingkungan belajar di sekolah itu kurang tepat.

Kata kunci: Lingkungan belajar TK, indoor, outdoor

\section{PENDAHULUAN}

Periode anak usia dini atau masa pra sekolah adalah periode rentan. Setiap anak rentan ketika menerima stimulus apapun, selama fungsi kejiwaan/mental dan jasmani sudah mulai siap untuk merespon setiap rangsangan yang diterima dari lingkungan sekitarnya. Sehingga, lingkungan disekitar anak perlu diperhatikan karena lingkungan merupakan unsur utama yang memberikan rangsangan kepada anak. Diperlukan perencanaan dan penataan lingkungan yang sesuai dengan kebutuhan anak-anak. Perkembangan anak dapat berkembang dengan baik jika lingkungan belajar anak dirancang dengan baik. Sebaiknya, lingkungan belajar anak usia dini tersedia sarana dan prasarana yang dapat membangkitkan minat anak untuk belajar serta anak bebas untuk bergerak, berkarya, bereksploarsi dan berbagai aktifitas lainnya sehingga dari aktifitasaktifitasnya anak memperoleh karakter baru. Lingkungan belajar indoor dapat digunakan anak sebagai tempat untuk mempertajam kemampuan anak. Ukuran ruangan, keadaan lantai, dinding kelas, atap langit-langit dan lain-lain perlu diperhatikanadar dapat menciptakan lingkungan belajar anak menyenangkan dan (Mariyana, Dkk). aktifitas lingkungan outdoor merupakan bagian terpadu dari rencana pembelajaran dan pengembangan anak-anak. Lingkungan belajar outdoor bermanfaat serta efektif dalam menunjang berbagai aspek perkembangan anak yang kecerdasan jamak yang beragam. Dengan demikian, lingkungan belajar outdoor diharapkan ditata dengan baik dan 
teratur. Sangat penting mempersiapkan lingkungan belajar yang mendukung agar anak usia dini dapat distimulus dan berbagai potensinya dapat berkembang.

Berdasarkan hasil penelitian Afoma R. Okudo Christy Omotuyole, (2014) bahwa lingkungan belajar anak usia dini diharapkan mempersiapkan sarana dan prasarana untuk kemampuan bahasa anak-anak dan perkembangan keseluruhan dari konten dan sikap belajar anak sehingga ciri khas lingkungan belajar anak usia dini diharapkan berbeda dari orang dewasa. Riset ini menerangkan bahwa adanya perbedaan lingkungan belajar anak usia dini dengan orang dewasa serta lingkungan belajar anak diharapkan dapat memfasilitasi perkembangan dan mengoptimalisasi kecerdasan anak.

Pada situasi pandemi, banyak sekolah yang melaksanakan pembelajaran daring sehingga sekolah-sekolah di tutup sementara. Anak hanya belajar dari rumah dan guru membimbing melalui virtual. Kondisi seperti ini membuat tujuan pembelajaran kurang terlaksana dengan baik karena guru hanya dapat mengkontrol anak melalui media online. Namun setelah memasuki era new normal guru dan peserta didik diperbolehkan belajar tatap muka namun tetap menggunakan protokol kesehatan. Setelah hampir satu tahun/ dua semester melakukan pembelajaran daring di mana guru tidak melakukan penataan lingkungan belajar di sekolah pada akhirnya setelah memasuki era new normal yang kemudian membuat pembelajaran bisa kembali tatap muka, guru harus mampu menyesuaikan pembelajaran yang akan di rancang sesuai dengan era new normal ini. Selain itu guru juga harus menata kembali lingkungan pembelajaran anak di sekolah karena berbeda pembelajaran yang dilakukan di rumah melalui online dengan pembelajaran langsung. Guru harus menata kembali lingkungan pembelajaran yang menarik dan aman bagi anak agar anak merasa nyaman belajar kembali di sekolah.

Dalam melaksanakan pembelajaran di era new normal, guru harus menata kembali lingkungan belajar dengan kreatif sehingga anak merasa nyaman berada di sekolah itu. Sesuai yang dilakukan guru TK Matuari Werot, guru tersebut menata lingkungan pembelajaran cukup baik sehingga anak-anak merasa nyaman berada di sekolah. Dari observasi awal peneliti mendapati bahwa lingkungan belajar di TK Matuari Werot sudah cukup baik namun kurang saja fasilitas yang digunakan dalam lingkungan belajar indoor maupun outdoor serta penempatan alat permainan yang ada kurang tepat, dimana permainan perosotan yang seharusnya menjadi salah satu fasilitas belajar lingkungan outdoor diletakan di dalam ruangan.

\section{METODE}

Penelitian ini menggunakan metode kualitatif deskriptif. Adapun teknik pengumpulan data yaitu observasi dan wawancara. Penelitian ini dilaksanakan pada bulan Mei 2021. Tempat pelaksanaan penelitian yaitu Desa Werot Kecamatan Likupang Selatan Kabupaten Minahasa Utara tepatnya di sekolah TK Matuari Werot. Dan, yang menjadi informan yaitu bunda yang mengajar di TK Matuari Werot.

\section{HASIL DAN PEMBAHASAN}

Dalam pembelajaran, lingkungan pembelajaran merupakan suatu hal yang perlu diperhatikan, melalui lingkungan belajar anak dapat mengembangkan berbagai aspek perkembangannya. Secara sederhana lingkungan belajar dapat diartikan sebagai suatu tempat atau suasana yang dapat mempengaruhi proses perubahan tingkah laku peserta didik. (Maryana et al, 2010, p17) Lingkungan pembelajar juga dapat diartikan sebagai 
laboratorium atau tempat dimana peserta didik dapat berkreasi, bereksplorasi, bereksperimen dan mengekspresikan diri sendiri untuk dapat mencapai hasil belajar.

Berdasarkan hasil riset yang dilakukan di TK Matuari Werot, diperoleh data bahwa lingkungan pembelajaran sudah cukup baik dikarenakan fasilitas yang ada di TK tersebut sudah memenuhi kebutuhan yang ada di sekolah itu, ungkap bunda Olvi selaku guru di TK Matuari Werot. Namun, berdasarkan observasi yang dilakukan peneliti didapati bahwa penataan lingkungan belajar di sekolah itu kurang tepat dan kurang lengkap. Berikut pejelasannya:

\section{Lingkungan belajar indoor}

Lingkungan sebagai komponen yang menyediakan berbagai stimulus yang perlu diperhatikan serta dipersiapkan dengan baik agar dapat menyiapkan objek-objek sesuai dengan apa yang dibutuhkan anak. Pendidik harus mempersiapkan serta menyiapkan lingkungan belajar yang menunjang dan memudahkan sensori anak untuk berinteraksi dengan lingkungan belajar sehingga berbagai aspek perkembangan anak berkembang secara optimal. Khususnya lingkungan indoor, ukuran ruangan, keadaan lantai, keadaan dinding, keadaan atap, dan lain sebagainya perlu diperhatikan agar dapat menciptakan lingkungan belajar yang sesuai dengan kebutuhan anak. (2010, p.34) yaitu:

Dalam lingkungan pembelajaran indoor terdapat beberapa area belajar,

1) Area balok

2) Area bermain drama

3) Area seni dan musik

4) Area permainan pasir dan air

5) Area permainan manipulasi

6) Area hewan dan tumbuhan atau area sains

7) Area pengembangan agama

8) Area matematika

Guru perlu mengatur dan menata lingkungan belajar indoor dari setiap area yang akan digunakan dalam kegiatan belajar anak, guru harus menyediakan peralatan yang akan dipakai untuk menunjang kegiatan belajar anak disetiap area belajar.

Berdasarkan observasi yang dilakukan peneliti, sudah ada beberapa area belajar yang ada pada TK Matuari Werot salah satunya adalah area matematika. Dalam area matematika di TK Matuari Werot terdapat beberapa fasilitas penunjang yaitu poster angka dan papan tulis. Selain itu ukuran ruangan juga sesuai dengan jumlah peserta didik. Ukuran ruangan kelas yaitu 4 x $7 \mathrm{~m}$ dan jumlah siswa yaitu 11 orang. Ukuran kelas tersebut cukup baik, peserta didik dapat beraktifitas dengan bebas. Bagian atap juga cukup baik karena letaknya tidak terlalu pendek sehingga anak-anak bisa beraktfitas dengan bebas. Jadi lingkungan belajar di TK Matuari Werot dapat dikatakan baik sehingga berbagai aspek perkembangan anak dapat berkembang dengan baik. 


\section{Lingkungan belajar outdoor}

Bermain outdoor dapat membuat anak merasa senang dan dapat membantu pertumbuhan dan perkembangannya. Penataan lingkungan outdoor perlu diperhatikan untuk menunjang pertumbuhan dan perkembangan anak. Dengan demikian kita harus merancang tempat bermain outdoor sebaik mungkin. Sarana dan area belajar dalam lingkungan outdoor diharapkan dirancang secara efektif sehingga mampu mengembangkan perkembangan belajar anak secara keseluruhan.

Demikian ada beberapa sarana yang cocok untuk kegiatan serta diharapkan dapat mencapai berbagai tujuan perkembangan bagi anak di sekolah, yaitu:
1. Ayunan
2. Tangga yang dipasang di tanah
3. Tempat bangunan balok
4. Luncuran Tempat bangunan balok
5. Terowongan mini
6. Kayu atau bangku rendah untuk dikangkangi atau dipanjat
7. Tempat bermain pasir dan air
8. Lingkungan alamiah seperti pohon

Lingkungan belajar outdoor perlu diperhatikan yang benar-benar aman untuk anak. Untuk menjamin dan menghindari sesuatu yang tidak diinginkan sebaiknya, lingkungan pembelajaran diatur atau ditata dengan baik. Berdasarkan riset, peneliti menemukan bahwa keadaan lingkungan belajar outdoor di sekolah Tk Matuari Werot kurang aman bagi anak-anak dengan tidak adanya rumput hijau melinkan hanya krikil-krikil yang dapat membahayakan anak melakukan aktivitas bermain outdoor. Posisi gedung sekolah berada di samping jalan dengan pagar yang tidak utuh sehingga tidak dapat menjamin keamanan anak saat bermain. Dan alat permainan outdor hanya satu yaitu perosotan serta alat permainan ini juga diletakan di dalam ruangan sehingga mengurangkan esensinya sebagai permainan outdoor.

Bagi peneliti alat bermain outdoor tersebut belum lengkap atau belum memenuhi kebutuhan bermain anak. Namun, menurut Ibu Olvi yang adalah guru di TK Matuari Werot alat bermain outdoor tersebut sudah memenuhi kebutuhan bermain anak.

\section{Pentingnya Penyediaan Lingkungan Kondusif Bagi Anak}

Periode anak usia dini atau prasekolah adalah masa dimana anak peka terhadap lingkungan yang ada disekitarnya, anak sensitif ketika menerima berbagai stimulus, yaitu pada fungsi fisik maupun psikis telah siap merspon berbagai stimulus yang diterima dari lingkungan. Dalam hal ini, lingkungan dipandang sebagai unsur yang memberikan berbagai stimulus sehingga benarbenar harus diperhatikan. Dibutuhkan perancangan optimal agar dapat menghasilkan lingkungan yang sesuai dengan kebutuhan anak serta dapat mengembangkan berbagai aspek perkembangan. Gagne (1998) menyatakan bahwa peristiwa-peristiwa pada lingkungan akan mempengaruhi hasil belajar anak. Lingkungan yang tersusun, terencana dan teratur akan membantu mendapatkan respon yang sesuai dengan peserta didik. (Semiawan, 2002). 
Semakin baik lingkungan belajar dipersiapkan maka semakin tinggi dampak positif yang di dapatkan peserta didik. Maka dari itu, guru diharapkan mampu mempersiapkan lingkungan belajar yang dapat mengembangkan seluruh aspek perkembangan anak dengan baik.

Berdasarkan hasil penelitian, kondisi lingkungan belajar di TK Matuari Werot sudah cukup baik dikarenakan guru di sekolah tersebut mampu menata lingkungan belajar dengan baik sehingga pembelajaran terlaksana, hanya saja penempatan alat permainan outdoor kurang tepat penempatannya, namun mekipun diletakan dalam ruangan, peserta didik tetap menggunakan permainan itu sehingga fungsi dari permainan outdoor tetap terlaksana. Dalam lingkungan pembelajaran indoor guru juga menyediakan poster huruf dan angka, papan tulis, serta meja dan kursi yang sesuai dengan ukuran badan anak sehingga anak merasa nyaman ketika belajar. Ruangan kelas juga memiliki fentilasi sehingga ada sirkulasi udara di kelas itu. Atap dari kelas itu juga cukup baik karena tidak terlalu pendek sehingga ruangan kelas nyaman serta guru dan peserta didik bisa leluasa dalam melakukan aktifitas pembelajaran.

\section{SIMPULAN DAN SARAN}

Dari hasil dan pembahasan dapat disimpulkan bahwa lingkungan pembelajaran merupakan suatu hal yang perlu diperhatikan, melalui lingkungan belajar anak dapat mengembangkan berbagai aspek perkembangannya. Secara sederhana lingkungan belajar dapat diartikan sebagai tempat atau suasana yang dapat berpengaruh terhadap proses perkembangan serta perubahan karakter peserta didik. Berdasarkan hasil penelitian, kondisi lingkungan belajar di TK Matuari Werot sudah cukup baik dikarenakan guru di sekolah tersebut mampu menata lingkungan belajar dengan baik sehingga pembelajaran terlaksana, hanya saja penempatan alat permainan outdoor kurang tepat penempatannya, namun mekipun diletakan dalam ruangan, peserta didik tetap menggunakan permainan itu sehingga fungsi dari permainan outdoor tetap terlaksana.

Berdasarkan penelitian, penulis mengajukan beberapa saran yang perlu dilakukan yaitu:

1. Bagi Guru

Dalam pembelajaran luring ini guru diharapkan untuk lebih memperhatikan kondisi lingkungan belajar anak dan juga penempatan alat permainan outdoor. Penempatan diharapkan sesuai dengan situasi serta keadaan yang terjadi di sekolah itu.

2. Bagi Orang tua

Diharapkan agar dapat bekerja sama dengan guru dalam membantu proses pembelajaran anak. 


\section{DAFTAR PUSTAKA}

Conny R, S. (2002). Belajar dan Pembelajaran dalam Tarap Usia Dini (Pendidikan Prasekolah dan Sekolah Dasar). Jakarta: PT Prenhalindo.

Omotuyole, A. (2014). Echanced Learning Environment and Its Implications On the Pre-school Children's Language Performance. European Scientific Jurnal.

Rita, M. (2009). Pengelolaan Lingkungan Belajar . Jakarta: Prenada Media Grup.

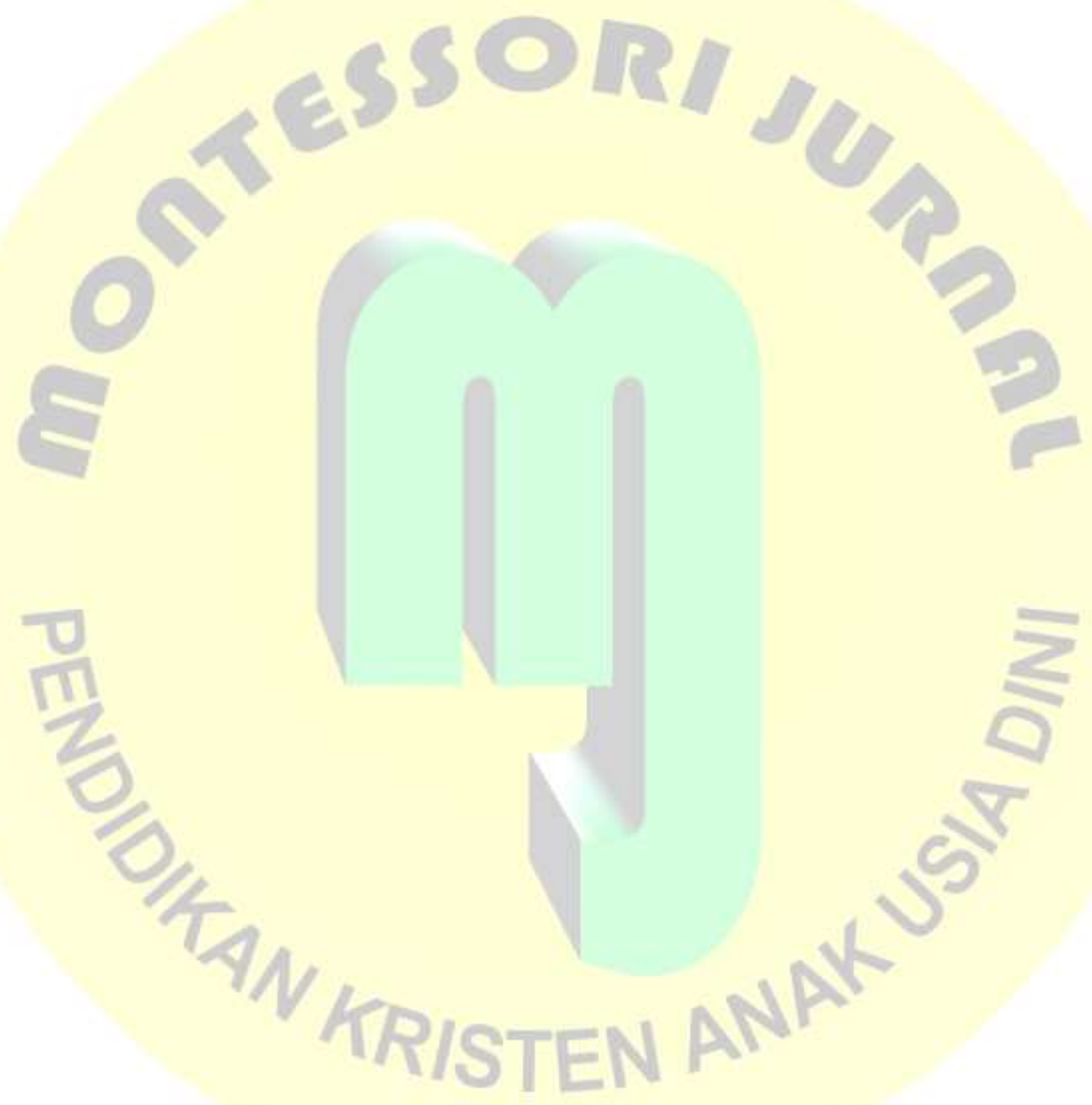

